\title{
Representation of inner, outer and expanding circle varieties and cultures in global ELT textbooks
}

\author{
Zia Tajeddin ${ }^{1^{*}}$ (B) and Maryam Pakzadian ${ }^{2}$
}

\author{
* Correspondence: zia_tajeddin@ \\ yahoo.com; tajeddinz@modares.ac.ir \\ ${ }^{1}$ Department of English Language \\ Teaching, Faculty of Humanities, \\ Tarbiat Modares University, Jalal \\ Ale-Ahmad Highway, Tehran, Iran \\ Full list of author information is \\ available at the end of the article
}

\begin{abstract}
The rise of world Englishes has challenged the emphasis on native-speaker accents and cultures in English language teaching. This study aimed to investigate the representation of world Englishes and cultures in three global language teaching textbooks, namely Interchange, English Result, and American English File. The textbooks were subjected to content analysis regarding their reference to Inner, Outer, and Expanding Circles' varieties and their associated cultural contents. Kachru (The alchemy of English: The spread functions and models of non-native Englishes. Oxford: Pergamon, 1986) notion of Concentric Circles, and the categorization proposed by Pfister and Borzelli (Unterrichtspraxis 10:102-108, 1977) functioned as a framework to see which aspects of each culture (social, personal, religion/arts/humanities, political systems and institutions, and environmental concerns) were addressed in these textbooks. Findings revealed that most of the references to the three circles and cultural elements embodied in the textbooks were toward Inner Circle countries in American English File. Furthermore, in Interchange and English Result series, reference to Outer and Expanding Circles' varieties and cultural elements were comparatively more evident. However, all the three textbook series mostly represented Inner-Circle accents. These findings have implications for materials developers to adopt an EILaware approach and to avoid the sole representation of native speakers' linguistic norms and cultures in ELT textbooks.
\end{abstract}

Keywords: Accent, Culture, English as an international language, Expanding circle, Inner circle, Outer circle, Textbooks

\section{Introduction}

Indisputably, the rise of globalization in conjunction with postcolonial trends has had a profound impact on the spread of English and English language teaching (ELT) in the world in the past two decades (Cameron \& Galloway, 2019; Cogo \& Dewey, 2012). The rapid profusion of English has motivated many scholars to study the plausibility of shifting from native models of pedagogy in ELT to English as an International Language (EIL), also termed as English as a lingua franca (ELF) despite terminological differences (Jenkins, 2009, 2015; Kirkpatrick, 2006, 2011; Matsuda, 2012, 2017; McKay \& Brown, 2016; Sharifian, 2009). EIL is a term used to portray the status of English as the world's

(c) The Author(s). 2020 Open Access This article is licensed under a Creative Commons Attribution 4.0 International License, which permits use, sharing, adaptation, distribution and reproduction in any medium or format, as long as you give appropriate credit to the original author(s) and the source, provide a link to the Creative Commons licence, and indicate if changes were made. The images or other third party material in this article are included in the article's Creative Commons licence, unless indicated otherwise in a credit line to the material. If material is not included in the article's Creative Commons licence and your intended use is not permitted by statutory regulation or exceeds the permitted use, you will need to obtain permission directly from the copyright holder. To view a copy of this licence, visit http://creativecommons.org/licenses/by/4.0/. 
second language and the commonest language utilized for global business, trade, travel, correspondence, and numerous others. Therefore, EIL is considered both as a type of English and as a way of using it (McKay, 2018) as with the term World Englishes (WE). The concept of EIL suggests that different norms exist for the use of English in different varieties of world Englishes around the globe (Matsuda, 2019; Richards \& Schmidt, 2002).

As indicated by Chang (2006), English has been the dominant foreign language in the institutional curricula and foreign language teaching and learning systems. This global status of English has brought about a powerful textbook publishing market. A useful ELT textbook can achieve sales exceeding thousands of copies a year. As noted by Cortazi and Jin (1999), textbooks play diverse roles in an EFL classroom, namely instructor, trainer, teaching resource, authority, and ideology. Since ELT textbooks are viewed as the heart of any ELT program, every textbook in the curricula is required to be analyzed and evaluated before it is used in the classroom. Traditionally, it was presumed by curriculum developers that only American and British English should be included in the ESL/ EFL curricula. As the EFL textbooks, by default, have focused almost exclusively on these native varieties of English, multiple legitimate varieties of worlds English have been underrepresented in ELT textbooks (Matsuda, 2002). The emergence of other intelligible varieties happened when Kachru (1986) described the diffusion of English in terms of three concentric circles: The Inner Circle, The Outer Circle, and the Expanding Circle. Kachru argued that these circles establish "three distinct types of speech fellowships of English, phases of the spread of the language, and particular characteristics of the uses of the language and of its acquisition and linguistic innovations" (p. 122).

Over the past two decades, many researchers have discussed the features of EIL (Alptekin, 2002; Brown, 2012; Deterding \& Kirkpatrick, 2006; Matsuda, 2012; Mckay, 2012; Nguyen, Marlina, \& Cao, 2020; Tajeddin, Alemi, \& Pashmforoosh, 2018), ELF (Caleffi, 2016; Siqueira, 2015; Takahashi, 2011), and Global English (GE) (Gerday, 2019; Gray, 2010; Joo, Chik, \& Djonov, 2019; Syrbe \& Rose, 2018; Vettorel \& Lopriore, 2017) in curriculum development and teaching materials. Other studies have investigated culture-related content and representation of cultures in textbook materials (e.g., Sadeghi \& Sepahi, 2018; Setyono \& Puji Widodo, 2019). Although ELT materials representing the Inner Circle countries' cultural norms and values should be incorporated in ELT textbooks, the ever-growing number of English varieties in Outer and Expanding Circle countries demands more attention to the cultural norms and values of these countries (McKay, 2003; Nguyen, 2011). If the principal pedagogical goal of ELT is to educate L2 learners for the purpose of successful global communication, ELT textbooks should represent not only the Inner Circle culture and varieties but also the Outer and Expanding Circle ones. This will assist L2 learners to negotiate their perception of the interlocutors' values and that of themselves to build solidarity (Nguyen, 2011). However, only few studies have evaluated ELT textbooks regarding the representation of world Englishes and concentric cultures (e.g., Cook, 2008; Gray, 2002; Hanashiro, 2016; Rashidi, Meihami, \& Gritter, 2016; Tajeddin \& Teimournezhad, 2015; Vettorel, 2010, 2018; Yamanaka, 2006). To bridge this gap, this study set out to investigate the content of three global ELT textbooks akin to their representation of world Englishes and Inner, Outer, and Expanding Circle countries' cultures.

\section{Literature review}

\section{EIL and language education}

To date, a great deal has been written about the principles and practices of EIL (e.g., Alsagoff, McKay, Hu, \& Renandya, 2012; Jenkins, 2000; Matsuda, 2012, 2017; McKay \& 
Brown, 2016; Sharifian, 2009). Scholars advocate an EIL approach to teaching English for a number of reasons. The main rationale is that the majority of English speakers are not native speakers (NSs) of the language. Therefore, we need to reconceptualize what English is and break faith in the common belief that native speakerism should be regarded as the norm in ELT (Holliday, 2005). Sharifian (2009) emphasizes that EIL is not confined to a specific variety of English. He drew a distinction between EIL and International English by arguing that EIL is the language of international and intercultural relations which "rejects the idea of any particular variety being selected as a lingua franca for international communication" (p. 2). Acknowledging the differences between EIL, ELF, and WE, Sifakis (2019) argues that we can use GE as an umbrella term to refer to all types of interaction between people with different mother tongues.

Irrespective of these terminological confusions and complexities, Kachru $(1986,1992)$ distinguishes between three concentric circles in his attempts to describe the spread of English. The Inner Circle includes countries such as the United Kingdom, the United States, Canada, Australia, and New Zealand, where English is used as the first language. The Outer Circle consists of countries where English is used as a second language in multilingual settings such as Malaysia, Singapore, India, Nigeria, and their English is norm-developing. Finally, the Expanding Circle refers to countries where English is used as a foreign language for international communication such as Japan, China, Iran, Saudi Arabia, and South Korea, and their English is considered as norm-dependent. The majority of English users are bilingual or multilingual speakers from the Outer and Expanding circle countries.

According to Widdowson (1994), native-speakerism is outdated and NSs are no more the sole owners of the English language. He castigates native-speaker custodians for their concern about the diversity of English and the fragmentation of English into mutually unintelligible variants. He points out that English with its many varieties is utilized for a variety of activities in various settings around the globe. Therefore, English is going to be influenced by both its native and nonnative speakers (Crystal, 2012). Sifakis and Bayyurt (2017) maintain that tasks and activities should be designed to raise the awareness of learners about EIL/ELF and to aid them in revisiting their attitudes toward standard varieties and norms. Phan (2009) argues that learners can take the ownership of English despite being proud of their local culture and identity and in this way reassert and preserve their identity. Therefore, Parmegiani (2014) coined (dis) ownership of English as a collective claim to English as everybody's language that belongs to all its speakers around the world.

In the EIL paradigm, English is considered as a means to present one's own identity and local culture to others around the globe (McKay, 2003). As such, Brown (2007) suggests that "our zeal for spreading English needs to be accompanied by concurrent efforts to value home languages and cultures" (p.7). Similarly Sharifian (2018) maintains that we should try to bring global and local forces together in a dual process which may be referred to as the glocalization of the language. The most significant areas of ELT for glocalization are materials development and curriculum design.

Beyond simply shifting the focus from target language accents and culture in the Inner Circle to the mix of English varieties from Inner, Outer and Expanding Circles in the local context, local resources and constraints on curriculum development must be accommodated in EIL needs analysis (Brown, 2009; Long, 2005). To insure EIL curriculum success, local teachers and other stakeholders must be assigned agency in setting the objectives so that they can have a strong sense of ownership (Brown, 1995). Based 
on an in-depth analysis of published ELT textbooks in Inner Circle countries, Gray (2002) concludes that these textbooks are primarily promoters of social messages and particular ways of living. As such, "if we wish to empower English language learners (ESLs) and help them overcome the native-speakers bias, we need to ensure that teachers who work directly with them are respectful and accepting of the linguistic and functional diversity that exists in English today" (Ates, Eslami, \& Wright, 2015, p. 486).

\section{EIL and language teaching textbooks}

A principal criterion for EIL textbook development is to expose learners to different varieties of English to raise their awareness about the diversity of accents and cultures in world Englishes. EIL teachers and learners are more willing to preserve their own local cultural and linguistic identities as their awareness of identity issues raised by globalization increases. English, as it is presented in EIL, is in search of deterritorialization (Canagarajah, 2005) and denationalization (Smith, 1976, as cited in McKay, 2002) as it is glocally situated in multilingual contexts alongside other local languages and cultures (Brutt-Griffler, 2002). Additionally, McKay (2002) accentuates the role of culture in the teaching of EIL where teaching English could be established in the local cultures and identities of its users. McKay proposes that three main sources can inform the development of language teaching materials: English-speaking countries' culture, local culture, and international culture. This entails the adoption of a reflective approach to the instruction of culture in EIL teaching to expand an ethos of interculturalism (Byram, 1998). Similarly, Cortazzi and Jin (1999) distinguish between three ways of presenting culture in ELT textbooks and materials: (a) source culture, which includes learners' local culture; (b) target culture, which draws on the culture of Inner Circle nations; and (c) international culture, which refers to a variety of cultures from all around the globe. Matsuda (2012) explains that cultural content in general English courses must be selected from multiple sources as learners should be prepared for intercultural communication in international contexts. These sources can include a range of topics on peace and environment which foster the sense of global citizenship among learners.

English textbooks can exert a profound effect on learners' understanding of English varieties and cultures. They can also impact the degree of teachers' emphasis on EILaware activities in the classroom. Therefore, ELT textbook analysis from the standpoint of English varieties and cultures can provide valuable insights into teaching practice. A number of textbook analyses have been conducted from this perspective. For instance, Matsuda (2002), in her analysis of seven 7th-grade textbooks in Japan from 1997 to 2002 based on Kachru's model of circles, found that the majority of non-Japanese main characters in these textbooks were from Inner-Circle cultures, mainly the US, Canada, Australia, and Scotland. Furthermore, these characters were likely to produce more words, to play more significant roles, and to contribute significantly to the dialogs. Yamanaka (2006) conducted a study in Japan to see which countries were represented in junior and senior high school English language textbooks based on Kachru's concentric model. Analysis of textbooks revealed that there were cultural biases toward the USA. Findings showed that there was a marked lack of emphasis on Outer Circle countries compared with countries in the Inner Circle. Moreover, countries in the Expanding Circle, except for Japan which dominated cultural items in English textbooks, 
appeared rather low. To provide evidence for the NS stance in ELT materials, Tomlinson and Masuhara (2013) conducted a long-term textbook analysis to evaluate the effectiveness of the textbooks. They found that the textbooks under evaluation included primarily educated British English norms. Further, the study documented instances of ELF in the book The Big Picture. However, even in those rare cases, "the photos of foreign people make them seem like exotic beings rather than, possibly, ELF users" (p. 244). In Japan, Hanashiro (2016) explored the portrayal of countries and cultural representations in Japanese EFL high-school textbooks drawing upon Kachru's model. Three books were examined with regard to their representation of English language varieties and cultural elements. The findings showed that these three textbooks were likely to include primarily Inner Circle nations at the expense of Outer and Expanding Circle nations.

Rashidi et al. (2016) selected and analyzed three ELT textbook series from Inner, Outer, and Expanding Circle countries. The findings of their study indicated that there were differences among the ELT textbooks of the three concentric circles. While the ELT textbooks of the Inner Circle involved more L2 cultural content, the ELT textbooks of the Expanding Circle involved more L1 and international cultural content. Furthermore, the ELT textbooks of the Outer Circle intended to contain L1, L2, and international cultural content. Regarding the cultural elements, the Inner and Outer Circle textbooks involved more L2 aesthetic cultural elements, whereas the Expanding Circle ELT textbooks showed tendency toward their cultural elements through L1 aesthetic and sociolinguistic senses of culture. In another study, Vettorel (2018) examined textbooks published by Italian and international publishers from the 1990s to 2015 in terms of their representation of activities and tasks related to ELF-informed communication strategies. The findings showed that, except a few cases, textbook did not pay consistent attention to this important area. In another context, Syrbe and Rose (2018) analyzed three main textbook series used in Germany through an adapted framework that shows a Global Englishes approach to language teaching, highlighting depictions of ownership, interlocutors, models, and target speakers of English. Findings revealed that there was over-reliance of UK models of English, and static representations of language users and cultures. Looking at the cultural content of a nationally adopted EFL textbook in Indonesia, Setyono and Puji Widodo (2019) investigated the represented multicultural values in the EFL textbook suited for senior high school students. Findings of the study indicated that four themes of multicultural values emerged from the textbook, such as (1) respect for cultures of various ethnic and religious groups; (2) respect for cultures of indigenous peoples; (3) conflict avoidance and peace with all manifestations of life and nature; and (4) acknowledgement of creative cultural products. The authors concluded that as English plays an increasingly significant role as a global lingua franca, multicultural materials from Outer and Expanding Circle countries need to be added to ELT textbooks. In tandem, English teachers should creatively instruct multicultural aspects and utilize multimodal materials to engage learners in culturally laden language-learning tasks.

More recently, Joo et al. (2019) examined five EFL textbooks approved by the South Korean government for use in Grade 3. The aim was to unravel whether and how the multimodal resources used in these textbooks addressed the curriculum requirement to present English as an important means to bridge different countries. The critical multimodal content analysis of characters and their interactions in the textbook indicated that a general western bias and implicit endorsement of native-speakerism exist in 
Korean EFL textbooks. Along the same line, Nguyen et al. (2020) explored the extent to which a set of locally developed English textbooks in Vietnam are aligned with the EIL-informed pedagogy and prepare learners to use English for intercultural communication. The findings revealed that while international communication may engage a broad spectrum of global English users, the books orient toward preparing learners to use English for communication with Anglophone English speakers, thus only partially serving the learners' multiple communicative needs in the real world. Their findings highlight the significance of adopting an EIL oriented approach in ELT materials development and use, as well as encouraging discourses of globalization and multilingualism, and refraining from ideological biases.

As the preceding review shows, the representation of world Englishes and cultures in ELT textbooks from an EIL vantage point is still under-researched. To address this gap, this study aimed to analyze three popular global ELT textbooks with regard to their representation of concentric countries and different varies of world Englishes. For this purpose, the following questions were investigated:

1. How do ELT textbooks differ in representing Inner, Outer, and Expanding Circle countries' cultures?

2. How do ELT textbooks differ in the representation of varieties of world Englishes?

\section{Method}

\section{Textbook Corpus}

Three textbooks from three popular English language teaching series were chosen: Interchange Third Edition Student Book 2 (Richards, Hull, \& Proctor, 2005), English Result Student Book 3 (McKenna, McDonald, \& Hancock, 2008), and American English File Second Edition Student Book 3 (Latham \& Oxenden, 2014). For the purpose of comparability, all the three student books were selected from the intermediate level and all the audio tracks (monologs and conversations) were subjected to content analysis. Elementary students' minimal knowledge of English permits only the introduction of surface cultural concepts in Elementary series; hence, deep cultural concepts can be introduced as language proficiency increases in the intermediate level. Therefore, the inclusion of Outer and Expanding Circle varieties and cultures mostly happens in intermediate series. Interchange Third Edition Level 2 Student Book contains 16 units and 45 listening and conversation audio tracks (176 pages). English Result Intermediate Student Book 3 (B1-B2) includes 12 units and 73 recording tracks including conversations, monolog, and media (160 pages). American English File Second Edition Book 3 includes 10 units and 51 listening audio tracks (168 pages). The lesson division varies in each textbook. These textbooks have been taught broadly in different countries around the world. Our choice of the three EFL textbooks, namely, Interchange, English Result, and American English File was due to the fact that these textbooks have been taught broadly in different countries around the world and also in the context of this study and they were among the top three popular English course books at English language institutes in Iran.

\section{Data analysis framework}

Two frameworks were adopted to evaluate the textbooks in this study: Kachru's (1986) Concentric Circles model and Pfister and Borzelli's (1977) categorization. The following 
criteria were considered in analyzing the textbook corpus: reference to Inner Circle nations, reference to Outer and Expanding Circle nations, and frequency of nonnative accents. The frequency of references to Outer and Expanding Circle nations shows adherence to the EIL paradigm. Inclusion of nonnative accents is one of the main tenets of EIL, which is the acknowledgement of different varieties of world Englishes. To ascertain the reference to the cultures of Inner, Outer, and Expanding Circle nations, five general categories introduced by Pfister and Borzelli were considered. The categories include social, personal, religion/arts/humanities, politics and institutions, and environmental concerns. The social category incorporates leisure, populace/nationality, work, social class, and attitudes. For the personal aspect, consuming/shopping, family connections, and housing were considered. Religion/arts/humanities topics include writing, music, expressions, fables, history, and sacred places. The political category incorporates government, education, law, and equity. Environmental topics involve geography, natural resources, climate, financial development, and urban vs. rustic. We focused our attention on audio tracks of all the three textbooks as it was not possible to detect accents otherwise. Sentences in audio tracks were used as the unit of analysis. Frequencies and percentages were calculated.

\section{Results}

The first aim of the study was to explore how ELT textbooks differ in representing Inner, Outer, and Expanding Circle countries' cultures. Table 1 presents the frequency of reference to Inner Circle countries' culture. The percentages were calculated out of the total frequency of references to all nations from Inner, Outer, and Expanding circles.

In Interchange Book 2, 35 (42.16\%) of the themes are concerned with Inner Circle countries (The US 25, Britain 5, Australia 3, Canada 2). They include all five aspects of the Pfister and Borzelli's (1977) categorization, such as American sportsmen, Hollywood actors/actresses, American movie directors, American novels (arts/humanities), American ski resorts and places in New York City (social), American presidents, Statue of Liberty (political), official languages of Canada (social), and finance in the US (environmental), and family connection in the US (personal).

In English Result Book 3, 45 (45.91\%) of references to countries include Inner Circle ones, and almost predominantly the US (The US 23, Britain 12, Australia 5, Canada 5). They cover politics and main parties in the US (political), summer festivals and parks in the UK (social), shopping in New York (personal), Shakespeare (arts/humanities), finance in the UK (environmental), and British tourism (social). Units include all the five categories of cultural themes by addressing their history, geography, social customs, people, and laws.

In American English File Book 3, 46 (63.01\%) of references to countries are focused on Inner Circle nations (The US 33, Britain 10, Australia 1, Canada 2), and all five categories in Pfister and Borzelli's (1977) categorization were covered, such as American actors/actresses and musicians (arts/humanities), urban life in New York City (environmental), American educational system (political), American family connections (personal), and summer festivals and parks in the UK (social).

Table 2 shows the number of references to Outer and Expanding Circle countries. The percentage values were calculated out of the total number of references to Inner, Outer, and Expanding Circle nations. 
Table 1 Frequency of references to inner circle countries

\begin{tabular}{|c|c|c|c|c|}
\hline Book & Country & $\mathrm{N}$ & $\%$ & Target cultural themes \\
\hline \multirow{4}{*}{$\begin{array}{l}\text { Interchange Third } \\
\text { Edition, Intermediate } \\
\text { Book } 2\end{array}$} & The US & 25 & \multirow[t]{4}{*}{42.16} & Social, personal, arts, politics, environment \\
\hline & Britain & 5 & & (General: travel, childhood, customs, personality, and predicaments, \\
\hline & Australia & 3 & & $\begin{array}{l}\text { change, abilities and skills, countries, facts, experiences, movies and } \\
\text { books, body language, emotions, future, giving advices and } \\
\text { suggestions, invitations and excuses, describing people, museums, } \\
\text { child prodigies, authors, wisdom, advice columns, lying and truth, } \\
\text { etc.) }\end{array}$ \\
\hline & Canada & 2 & & $\begin{array}{l}\text { (Specific: Statue of Liberty, New York City, LA, American sportsmen } \\
\text { like Michael Jordan, Bill Gates, J.K. Rowling as a British author, } \\
\text { Brighton city, traffic and official languages in Canada, many } \\
\text { American actors and actresses including Kate Winslet, Tom Hanks, } \\
\text { Halle Berry, Johnny Depp, etc.) }\end{array}$ \\
\hline \multirow{5}{*}{$\begin{array}{l}\text { English Result } \\
\text { Intermediate } \\
\text { Book } 3\end{array}$} & The US & 23 & \multirow[t]{5}{*}{45.91} & Social, personal, art, politics, environment \\
\hline & Britain & 12 & & (General: people in one's life, customs, family, friends and \\
\hline & Australia & 5 & & \\
\hline & \multirow[t]{2}{*}{ Canada } & 5 & & $\begin{array}{l}\text { feelings, preferences, music, countries and governments, stories } \\
\text { and news, neighborhood, anecdote, fashion, applications, abilities, } \\
\text { future, looks, conversations, advices, unreal situations, opinions, } \\
\text { shopping habits, information, website recommendations, hopes } \\
\text { and wishes, important decisions, morals, etc.) }\end{array}$ \\
\hline & & & & $\begin{array}{l}\text { (Specific Examples: Oxford, Big Ben, Burberry raincoats, British } \\
\text { tourism business, Government buildings in US, finance in the UK, } \\
\text { Prince William, Queen Elizabeth, Prince Diana, Utah State } \\
\text { University; Shakespeare; Politics and main parties; etc.) }\end{array}$ \\
\hline \multirow{4}{*}{$\begin{array}{l}\text { American English File } \\
\text { Second Edition } \\
\text { Book } 3\end{array}$} & The US & 33 & \multirow[t]{4}{*}{63.01} & Social, personal, art, politics, environment \\
\hline & Britain & 10 & & \multirow{2}{*}{$\begin{array}{l}\text { (General: food, family, spending and saving money, changing lives, } \\
\text { races, stereotypes, failure and success, modern manners, sports, } \\
\text { movies, appearances, education, houses and ideal homes, } \\
\text { shopping, lucky encounters, electronic devices, modern icons, } \\
\text { crime, etc.) }\end{array}$} \\
\hline & Australia & 1 & & \\
\hline & Canada & 2 & & $\begin{array}{l}\text { (Specific: US presidents and British prime ministers, summer } \\
\text { festivals and parks in the UK, many references to London, } \\
\text { sightseeing and luxury hotels in New York, American culture, } \\
\text { Beatles, Bill Gates, John Lennon, etc.) }\end{array}$ \\
\hline
\end{tabular}

Table 2 shows the recurrence of cultural elements related to Outer and Expanding Circle nations. The three textbook series in the market represent less of these nations. The rates increase from $36.98 \%$ in American English file to $54.08 \%$ in English Result and $57.83 \%$ in Interchange. Among the nations introduced, Japan represents the highest number of references in both Interchange Book 2 and English Result Book 3.

In Interchange 2, with 57.83\% of references to Outer and Expanding Circle, most of the East Asian nations (China, Hong Kong, Japan, Macau, Mongolia, North Korea, South Korea, and Taiwan) are represented. Interestingly, a wide variety of cultural themes are used to ascertain reference to Outer and Expanding Circle countries. They incorporate personal, social, arts, humanities, religion, politics, and ecological matters. Examples of these references are Greek philosophy (arts/humanities), transportation system in Singapore (politics and institutions), Chusok in Korea and marriage in Malaysia (social), and fish head curry from Singapore and Chinese food (personal). In English Result Book 3, with 54.08\% of references, all five categories are reflected to include Outer and Expanding Circle countries. Examples are Anecdotes in Spanish, Vincent Van Gogh, Eiffel Tower and Louvre Museum (arts/humanities), Carnival in Brazil (social), Beijing visa rules, President Mandela and President of Tanzania 
Table 2 Frequency of references to outer and expanding circle countries

\begin{tabular}{|c|c|c|c|c|}
\hline Book & Country & Frequency & Percentage & International cultural themes \\
\hline $\begin{array}{l}\text { Interchange } \\
\text { Third } \\
\text { Edition } \\
\text { Book } 2\end{array}$ & $\begin{array}{l}\text { Outer Circle: } \\
\text { Singapore (2) Malaysia (1) India (4) } \\
\text { Expanding Circle: } \\
\text { Argentina (2) Brazil (3) China (4) } \\
\text { Egypt (3) Columbia (1) } \\
\text { The Czech Republic (1) Japan (5) } \\
\text { Korea (5) Mexico (3) Paraguay (1) } \\
\text { Ecuador (1) Taiwan (China) (1) } \\
\text { France (2) Italy (2) Vietnam (2) Peru } \\
\text { (1) Chile (1) Germany (2) } \\
\text { Greece (1) }\end{array}$ & 48 & 57.83 & $\begin{array}{l}\text { social, humanities/arts, } \\
\text { politics, environment } \\
\text { (Examples: transportation system } \\
\text { and solution to traffic in Singapore, } \\
\text { travel to Ireland, capsule hotels in } \\
\text { Tokyo, Chinese food and parsley, a } \\
\text { vacation in Mexico, an Indian tribe } \\
\text { in Paraguay, marriage in Malaysia, } \\
\text { Great Wall of China, talking about } \\
\text { Colombia and its capital city } \\
\text { Bogota, a vacation in Italy, Greek } \\
\text { philosophy, etc.) }\end{array}$ \\
\hline $\begin{array}{l}\text { English } \\
\text { Result } \\
\text { Book } 3\end{array}$ & $\begin{array}{l}\text { Outer Circle: } \\
\text { India (5) Kenya (1) Zambia (2) } \\
\text { Tanzania (1) } \\
\text { Expanding Circle: } \\
\text { Mexico (2) Japan (5) Germany (2) } \\
\text { France(1) Korea (3) China (2) Chile } \\
\text { (2) Saudi Arabia (1) Egypt (2) } \\
\text { Indonesia (1) Hong Kong (China) } \\
\text { (3) Italy (4) Thailand (3) Taiwan } \\
\text { (China) (2) Venezuela (1) Spain (1) } \\
\text { Morocco (1) Bolivia (1) Austria (1) } \\
\text { Brazil (2) Bulgaria (1) The } \\
\text { Netherlands (1) South Africa (2) }\end{array}$ & 53 & 54.08 & $\begin{array}{l}\text { social, arts/religion, } \\
\text { environment, politics } \\
\text { (Examples: How to greet in China, } \\
\text { Korea, Japan, France and Saudi } \\
\text { Arabia; Prado museum in Madrid; } \\
\text { The life of a Muslim in Morocco; } \\
\text { Reference to Lake Titicaca in } \\
\text { Bolivia; Arabian desert; Beijing visa } \\
\text { rules; Mountains in Austria; Eiffel } \\
\text { Tower and Louvre museum; Pieces } \\
\text { in museum from Zambia, Ireland } \\
\text { and Brazil; Anecdotes in Spanish; } \\
\text { Cultural shock in Japan; Bombay } \\
\text { Palace; President Mandela; } \\
\text { president of Tanzania; Vincent Van } \\
\text { Gogh; Carnival in Brazil; etc.) }\end{array}$ \\
\hline $\begin{array}{l}\text { American } \\
\text { English File } \\
\text { Second } \\
\text { Edition } \\
\text { Book } 3\end{array}$ & $\begin{array}{l}\text { Outer Circle: } \\
\text { Singapore (2) Uganda (1) } \\
\text { Expanding Circle: } \\
\text { China (3) France (3) } \\
\text { Spain (4) } \\
\text { Rwanda (1) Myanmar (1) Poland (1) } \\
\text { Vietnam (1) Japan (2) } \\
\text { Germany (2) Brazil (1) } \\
\text { Poland (2) Greece (1) Italy (2) }\end{array}$ & 27 & 36.98 & $\begin{array}{l}\text { social, arts, religion, } \\
\text { environmental, political } \\
\text { (Examples: Trips to Uganda and } \\
\text { Rwanda to visit mountain gorillas, } \\
\text { Malaria, teaching to orphans in } \\
\text { least developed African countries, } \\
\text { trying traditional food in informal } \\
\text { places and restaurants in Spain, } \\
\text { meeting a friend from Burma- } \\
\text { Myanmar, Burmese culture, a Polish } \\
\text { producer in film industry and } \\
\text { Polish actors, a play about Romans, } \\
\text { Eiffel Tower, talking about famous } \\
\text { painters like Picasso and Matisse, } \\
\text { Sydney Airport, a house which } \\
\text { smelled like old Chinese food and } \\
\text { dirty clothes, Hamburg, travel to } \\
\text { Tokyo and Singapore, etc.) }\end{array}$ \\
\hline
\end{tabular}

(political), Lake Titicaca in Bolivia and Arabian deserts (environmental), and life of a Muslim in Morocco (personal). American English File, with 36.98\%, manifests the lowest number of references to Outer and Expanding Circle countries, though it includes all five categories in referring to non-Inner Circle nations. Examples of the references are Polish actors, a play about Romans, Eiffel Tower, talking about famous painters like Picasso and Matisse (arts/humanities), trying traditional food in informal places and restaurants (personal), teaching orphans in least developed African countries (political), travel to Tokyo and Singapore (social), and climate and Malaria disease in Africa (environmental).

The second aim of this study was to investigate how ELT textbooks differ in the representation of varieties of world Englishes. Table 3 shows the frequency and percentage of non-native accents found in the audio tracks of the books. 
Table 3 Percentage of non-native accents

\begin{tabular}{llll}
\hline Corpus & Number of speakers & Number of nonnative speakers & Percentage \\
\hline Interchange Third & 18 & 2 & 5.30 \\
Edition Book2 & & & 17.50 \\
English Result Book 3 & 26 & 4 & 8.10 \\
$\begin{array}{l}\text { American English File Second Edition } \\
\text { Book 3 }\end{array}$ & 37 & 3 & \\
\hline
\end{tabular}

Since the audio parts include both monologs and dialogs, the number of speakers was taken into account. Interchange 2 includes 5.30\% and American English File Book 3 embodies $8.10 \%$ of nonnative accents. Moreover, English Result Book 3, with $17.50 \%$, covers the highest number of non-native accents. They include accents from East Asia, MiddleEast, Latin America, and Europe. In Table 3, we focused on native/nonnative accent distinction. The reason is that in Table 2 we reported the references to different Inner, Outer and Expanding Circle countries and cultures based on what was mentioned in the book, but detecting the exact accent and dialect of the nonnative speakers is such a daunting task and needs an accent/dialect specialist. It's actually possible for ELT specialists to detect native (Inner Circle) accents, but not nonnative (Outer and Expanding Circle) ones. For example, it is a very demanding task and needs a professional linguist to detect the distinction between Singaporean, Chinese, and Japanese English.

\section{Discussion}

The main objective of this study was to analyze ELT textbooks regarding their adherence to the realization of EIL. To this end, three textbooks were selected and compared considering their reference to Inner, Outer, and Expanding Circle nations, including cultural themes which represent these countries and the inclusion of speakers with nonnative accents. The findings akin to the first research question show that American English File reflects the greatest number of references to Inner Circle nations. In the case of English Result and Interchange Third Edition, there is a considerable increase in recurrence of representing Outer and Expanding Circle nations. These findings also support those from other studies indicating that ELT textbooks are likely to include Inner Circle countries at the expense of Outer and Expanding Circle countries and that there is still a native speakerism bias toward Inner Circle countries (Ates et al., 2015; Gerday, 2019; Hanashiro, 2016; Joo et al., 2019; Matsuda, 2002; Tomlinson \& Masuhara, 2013; Yamanaka, 2006). The reason might be pursuing the "commercial success" which results in the exclusion of the global aspect of English (Gray, 2010, p. 109). However, these three textbooks, to some extent, represented various aspects of Outer and Expanding Circle nations. It seems that, as Rashidi et al. (2016) argue, the ELT textbook designers in the Inner Circle countries seek to represent their own cultural voices and values within the ELT textbooks designed for international use. This may be due to two main reasons. First, as Inner Circle ELT textbooks are partly aimed to be utilized in the country of their origin, the cultural content is in harmony with the inside needs. Second, as they are utilized internationally as well, the mostly hidden agenda of the Inner Circle ELT material designers is conveyed globally. According to Syrbe and Rose (2018), in countries where we have over-reliance on native models of English and static depictions of language users and cultures, the sociolinguistic reality of English is not accurately represented in ELT materials. 
Our textbook analysis revealed that American English File, Interchange, and English Result respectively used all five categories of cultural themes (personal, social, religion/ arts/humanities, political, and environmental) to ascertain reference to the target culture or the culture of Inner Circle countries, specially the US. These findings resonate with previous findings which indicate that ELT textbooks are largely representative of Inner Circle cultural and social values (Hanashiro, 2016; Tajeddin \& Teimournezhad, 2015; Tomlinson \& Masuhara, 2013; Xiaoqiong \& Xianxing, 2011). However, concerning Interchange and English Result, an inclination toward multiculturalism was observed. Moreover, the representation of cultural topics of Outer and Expanding Circle nations has become more miscellaneous while that of Inner Circle nations has diminished. The acknowledgement of different nations in Interchange and English Result shows more adherences to the standards of EIL. There are many arguments in favor of intercultural understanding and the inclusion of the culture of all three circles in ELT materials (Brutt-Griffler, 2002; Byram, 1998; Cortazi \& Jin, 1999; McKay, 2002; Sharifian, 2018). Furthermore, Kumaravadivelu $(2008,2012)$ argues that interculturalism is no longer sufficient for a globalized society of the twenty-first century, and instead cultural realism should be developed to raise global cultural awareness that may add to one's cultural horizons.

In all the three ELT textbooks, no reference was made to the learners' local culture, though this non-representation of the source culture seems quite understandable in international textbooks. These findings are in line with those studies which showed that the predominant culture category was the target culture with the least attention paid to source culture (e.g., Nguyen et al., 2020; Setyono \& Puji Widodo, 2019; Syrbe \& Rose, 2018). The reason for the absence of source-cultural content in ELT books might be due to the marketing considerations, as the inclination toward any source culture would prevent other countries from making use of the textbook (Alptekin, 2002). Moreover, it is usually difficult for NSs to collect accurate cultural data about other cultures around the world. Localization might be the solution to this problem as it helps use elements of the L1 culture to raise learners' awareness of their local cultural identity. However, the embodiment of the familiar L1 culture in the widely used global ELT series, such as Interchange, American English File, and English Result, may make the localized textbook seem less authentic and less appealing to the learners who consider global textbooks as sources of intercultural knowledge. Under the influence of new paradigms, such as EIL, ELF, and WE, global textbooks tend to reflect more of the Outer and Expanding culture to respond to the need for intercultural understanding. Furthermore, as the majority of real-life interactions in many international contexts are between non-native speakers, the cultural agenda of global ELT textbooks should be inclined more toward the inclusion of an "international culture," along with some degree of target-culture representation. Therefore, as Setyono and Puji Widodo (2019) suggest, multicultural materials from Outer and Expanding Circle countries need to be added to ELT textbooks.

As for the second research question, the content analysis of the dialogs and conversations in the three textbooks uncovered a visible distinction among them regarding the incorporation of non-native accents from non-English speaking nations. While American English File and Interchange included dialogs with local accents, English Result incorporated a wider variety of them. The listening tasks convey the persuasive message that 
speaking with a local accent is not slanderous and that EIL users should be enabled to comprehend individuals who speak English with their L1 accent. Among the three books, English Result incorporated more dialogs from non-English speaking nations though the frequency of these dialogs is still low compared that of the native ones. This finding is in line with the findings from other studies which indicated that ELT books mostly promote native accents (Gray, 2012; Hanashiro, 2016; Tomlinson \& Masuhara, 2013). As argued by Nguyen et al. (2020), the books primarily focus on preparing learners to use English for communication with Anglophone English speakers, thus only partially meeting the students' multiple communicative needs in the real world. Therefore, if English is to achieve genuine trustworthiness as a global language, it should recognize a pervasive phonology. Widely used language settings depict a more understandable view of the way English is utilized today (Jenkins, 2000). In these settings, bilingual English speakers make use of the language to communicate with one another as sightseers, guests, or businessmen in Outer and Expanding Circle nations (Widdowson, 1994). This is in sharp contrast with Cook's (2008) evaluation of some ELT materials in which L2 learners are basically demonstrated as sightseers or guests who obliviously ask for the address or urgently purchase things in English speaking countries. In many textbooks and language classrooms, inner circle nations are displayed as the standard, showing the predominant relationship between the core and the periphery (Phillipson, 2009). However, the rise of world Englishes and the international spread of English require learning tasks and activities in which learners are encouraged to preserve their own particular local linguistic features. This endeavor to connect the global with the local is in accordance with the view that the local is constantly embedded in the global or what is called "glocalization" (Sharifian, 2018).

\section{Conclusion}

This study set out to evaluate the content of three global ELT textbook series. The results revealed differences among the books regarding the recognition of the worldwide status of English and variety of world Englishes. While American English File was found to be the most Inner Circle-based textbook, English Result and Interchange adhered more to EIL tenets. The highest frequency of references to Inner Circle countries was related to the U.S. in all three textbooks. From this finding, it can be concluded that the three circle nations are not equally addressed in the ELT curriculum and textbooks so that learners cannot become communicatively competent and develop their linguistic competence (Matsuda, 2012). Therefore, to empower English language learners and help them overcome the native-speakers bias, we need to ensure that ELT textbooks give legitimacy to the linguistic and functional diversity that exists in EIL (Ates et al., 2015).

The results showed that American English File, Interchange, and English Result used all five categories of cultural themes (personal, social, religion/arts/humanities, politics and institutions, and environment) to ascertain reference to the culture of Inner Circle countries, especially US, and also Outer and Expanding Circle countries. Although these three textbooks used a wide range of cultural themes to cover the nations in the Concentric Circle, there is still room for the inclusion of international and local cultures all around the world. Accordingly, English materials developers and educators should ensure that the content of curriculum is not confined to the American or British culture. The books need to include cross-cultural elements, entailing reference to the target culture, the international culture, as well as the local culture of the learners, and 
provide authentic, real-life cultural contexts to raise the awareness of culture-specific features. As for the absence of the source culture in global textbooks, policymakers, and curriculum designers can promote the development of localized textbooks which include various features of the L1 culture. Local English teachers can use various cultural-comparison activities through texts, pictures, and videos to develop the intercultural sensitivity of the learners (Tajeddin \& Teimournezhad, 2015). Teacher educators should also help cross-culturally competent teachers to shoulder such responsibilities. Moreover, textbook developers should open up opportunities to encourage critical reflection among textbook users and consider the role of English in both local and lingua franca contexts (Galloway, 2017). The findings also demonstrated that English Result involves the highest representation of non-native accents compared with American English File and Interchange, which mostly depict American, British, Canadian, and Australian accents. Therefore, textbook developers should include a diversity of accents and intelligible varieties of English including both native and nonnative accents in ELT textbooks (Brown, 2012). Moreover, English language teacher should integrate other varieties of English into ELT textbooks and promote learners' knowledge about intelligible varieties of English by using successful EIL speakers as role models and motivators to compensate for the lack of EIL-informed textbook series.

It should be noted that the quantitative method used in the current study was subject to some limitations, which can affect the interpretation of our findings. In this study, only the intermediate series have been chosen. If all the volumes had been taken into account, a more detailed picture of the issue could have been provided. This study utilized frequency and percentages as the only tools for data analysis. Future studies could render more informative results by triangulating data by using different methods such as interviews to gauge the attitudes of textbook developers, teachers, and learners toward the linguistic and cultural content of ELT textbooks.

Acknowledgements

Not applicable.

\section{Authors' contributions}

The first author conceived of the study and decided on research questions, types of participants, instrumentation, data collection procedure, and data analysis. The first author also supervised the data collection and analysis procedures and helped draft and finalize the manuscript. The second author collected and analyzed the data and drafted the manuscript. Both authors read and approved the final manuscript.

Authors' information

1. Zia Tajeddin is Professor of Applied Linguistics at Tarbiat Modares University, Iran, where he teaches doctoral courses in L2 Pragmatics, Culture and Identity, and Second Language Teacher Education. He is co-editor of Applied Pragmatics (John Benjamins) and sits on the editorial/review board of journals such as RELC Journal and TESL-EJ. His research interests center on L2 pragmatics pedagogy, classroom discourse analysis, teacher identity and cognition, and EIL/ELF. He has presented papers in international conferences and published papers in many journals, including International Journal of Applied Linguistics, Journal of Language, Identity, \& Education, Pedagogies, The Language Learning Journal, Journal of Intercultural Communication Research, RELC Journal, Australian Journal of Teacher Education, The AsiaPacific Education Researcher, TESL-EJ, Language and Intercultural Communication, and TESL Canada Journal. 2. Maryam Pakzadian is a lecturer of Applied Linguistics at Isfahan University of Medical Sciences. She received her Ph.D. in Applied Linguistics from Allameh Tabataba'i University of Tehran, Iran. She has taught different undergraduate and graduate courses in Iranian universities. Her areas of interest include discourse analysis and interlanguage pragmatics, EIL, identity, and motivation.

Funding

There were no sources of funding for the research reported in this manuscript. 


\section{Competing interests}

The authors declare that they have no competing interests.

\section{Author details}

${ }^{1}$ Department of English Language Teaching, Faculty of Humanities, Tarbiat Modares University, Jalal Ale-Ahmad Highway, Tehran, Iran. ${ }^{2}$ Isfahan University of Medical Sciences, Tehran, Iran.

Received: 17 March 2020 Accepted: 24 June 2020

Published online: 02 July 2020

\section{References}

Alptekin, C. (2002). Towards intercultural communicative competence in ELT. ELT Journal, 56(1), 57-64.

Alsagoff, L., McKay, S. L., Hu, G. W., \& Renandya, W. A. (Eds.). (2012). Principles and practices for teaching English as an international language. New York, NY: Routledge.

Ates, B., Eslami, Z. R., \& Wright, K. L. (2015). Incorporating world Englishes into undergraduate ESL education courses. World Englishes, 34(3), 485-501.

Brown, H. D. (2007). Principles of language learning and teaching (5th ed.). White Plains, NY: Pearson Education.

Brown, J. D. (1995). The elements of language curriculum: A systematic approach to program development. New York, NY: Heinle $\&$ Heinle.

Brown, J. D. (2009). Foreign and second language needs analysis. In M. H. Long \& C. J. Doughty (Eds.), The handbook of language teaching (pp. 269-293). Oxford: Wiley-Blackwell.

Brown, J. D. (2012). ElL curriculum development. In L. Alsagoff, S. L. Mckay, G. Hu, \& W. A. Renandya (Eds.), Principles and practices for teaching English as an international language (pp. 147-167). New York, NY: Routledge.

Brutt-Griffler, J. (2002). World Englishes: A study of its development. Clevedon: Multilingual Matters.

Byram, M. (1998). Cultural identities in multilingual classrooms. In J. Cenoz \& F. Genesee (Eds.), Beyond bilingualism (pp. 96116). Clevedon: Multilingual Matters.

Caleffi, P. (2016). ELF in the speaking and listening activities of recently published English language course books. In L. Lopriore \& E. Grazzi (Eds.), Intercultural communication: New perspectives from ELF (pp. 63-82). Rome: Roma TRE-Press.

Cameron, A., \& Galloway, N. (2019). Local thoughts on global ideas: Pre- and in-service TESOL practitioners' attitudes to the pedagogical implications of the globalization of English. RELC Journal, 50(1), 149-163.

Canagarajah, S. (2005). Reclaiming the local in language policy and practice. Mahwah, NJ: Lawrence Erlbaum.

Chang, J. (2006). Globalization and English in Chinese higher education. World Englishes, 25(3-4), 513-525.

Cogo, A., \& Dewey, M. (2012). Analyzing English as a lingua franca: A corpus-driven investigation. London: Continuum.

Cook, V. (2008). Second language learning and language teaching (4th ed.). London: Hodder Education.

Cortazi, M., \& Jin, L. (1999). Cultural mirrors: Materials and methods in the EFL classroom. In E. Hinkel (Ed.), Culture in second language teaching (pp. 196-219). Cambridge: Cambridge University Press.

Crystal, D. (2012). A global language. In P. Seargeant \& J. Swann (Eds.), English in the world (pp. 151-177). Abingdon: Routledge/Open University.

Deterding, D., \& Kirkpatrick, A. (2006). Emerging South-East Asian Englishes and intelligibility. World Englishes, 25(3/4), 391-409.

Galloway, N. (2017). ELF and ELT teaching materials. In J. Jenkins, W. Baker, \& M. Dewey (Eds.), The Routledge handbook of English as a lingua franca (pp. 486-480). New York, NY: Routledge.

Gerday, L. (2019). What is 'global' in an ELT global coursebook? A linguistic analysis of the new headway upper-intermediate Student's book. English Text Construction, 12(1), 59-83.

Gray, J. (2002). The global course book in English language teaching. In D. Block \& D. Cameron (Eds.), Globalization and language teaching (pp. 151-167). London: Routledge.

Gray, J. (2010). The construction of English: Culture, consumerism and promotion in the ELT global coursebook. Basingstoke: Palgrave Macmillan.

Gray, J. (2012). English the industry. In A. Hewings \& C. Tagg (Eds.), The politics of English: conflict, competition, and co-existence (pp. 137-163). Milton Keynes: The Open University/Routledge.

Hanashiro, K. (2016). How globalism is represented in English textbooks in Japan, Hawaii Pacific University TESOL Working Paper Series (Vol. 14, pp. 2-13).

Holliday, A. (2005). The struggle to teach English as an international language. Oxford: Oxford University Press.

Jenkins, J. (2000). The phonology of English as an international language. Oxford: Oxford University Press.

Jenkins, J. (2009). World Englishes: A resource book for students (2nd ed.). Abingdon: Routledge.

Jenkins, J. (2015). Global Englishes: A resource book for students (3rd ed.). Abingdon: Routledge.

Joo, S. J., Chik, A., \& Djonov, E. (2019). The construal of English as a global language in Korean EFL textbooks for primary school children. Asian Englishes, 22, 1-17.

Kachru, B. B. (1986). The alchemy of English: The spread functions and models of non-native Englishes. Oxford: Pergamon.

Kachru, B. B. (1992). Teaching world Englishes. In B. B. Kachru (Ed.), The other tongue: English across cultures (2nd ed., pp. 355365). Urbana, IL: University of Illinois Press.

Kirkpatrick, A. (2006). Which model of English: Native-speaker, nativised or lingua franca? In R. Rubdy \& M. Saraceni (Eds.), English in the world: Global rules, global roles (pp. 71-83). London: Continuum.

Kirkpatrick, A. (2011). English as an Asian lingua franca and the multilingual model of ELT. Language Teaching, 44(2), $212-224$. Kumaravadivelu, B. (2008). Cultural globalization and language education. New Haven, CT: Yale University Press.

Kumaravadivelu, B. (2012). Individual identity, cultural globalization and teaching English as an international language: The case for an epistemic break. In L. Alsagoff, W. Renandya, G. Hu, \& S. L. Mckay (Eds.), Teaching English as an international language: Principles and practices (pp. 9-27). New York, NY: Routledge.

Latham, C., \& Oxenden, C. (2014). American English file (2nd ed.). Oxford: Oxford University Press.

Long, M. H. (Ed.). (2005). Second language needs analysis. Cambridge: Cambridge University Press.

Matsuda, A. (2002). International understanding through teaching world Englishes. World Englishes, 21(3), 436-440. 
Matsuda, A. (2012). Teaching material in EIL. In L. Alsagoff, G. Hu, S. L. Mckay, \& W. A. Renandya (Eds.), Principles and practices for teaching English as an international language (pp. 168-185). New York, NY: Routledge.

Matsuda, A. (2017). Preparing teachers to teach English as an international language. Bristol: Multilingual Matters.

Matsuda, A. (2019). World Englishes in English language teaching: Kachru's six fallacies and the TEIL paradigm. World Englishes, 38(1-2), 144-154.

McKay, S. (2002). Teaching English as an international language: The Chilean context. ELT Journal, 57(2), 139-148.

McKay, S. (2003). Toward an appropriate EIL pedagogy: Reexamining common ELT assumptions. International Journal of Applied Linguistics, 13(1), 1-22.

Mckay, S. L. (2012). Teaching materials for English as an international language. In A. Matsuda (Ed.), Principles and practices of teaching English as an International Language (pp. 70-83). Bristol: Multilingual Matters.

McKay, S. L. (2018). English as an international language: What it is and what it means for pedagogy. RELC Journal, 49(1), 923.

McKay, S. L., \& Brown, J. D. (2016). Teaching and assessing Ell in local contexts around the world. New York, NY: Routledge.

McKenna, J., McDonald, A., \& Hancock, M. (2008). English result. Oxford: Oxford University Press.

Nguyen, T. T. M. (2011). Learning to communicate in a globalized world: To what extent do school textbooks facilitate the development of intercultural pragmatic competence? RELC Journal, 42(1), 17-30.

Nguyen, T. T. M., Marlina, R., \& Cao, T. H. (2020). How well do ELT textbooks prepare students to use English in global contexts? An evaluation of the Vietnamese English textbooks from an English as an international language (EIL) perspective. Asian Englishes, 1-17. https://doi.org/10.1080/13488678.2020.1717794.

Parmegiani, A. (2014). The (dis) ownership of English: Language and identity construction among Zulu students at the University of KwaZulu-Natal. International Journal of Bilingual Education and Bilingualism, 17(6), 683-694.

Pfister, G. C., \& Borzelli, P. (1977). Surface cultural concepts: A design for the evaluation of cultural materials in textbooks. Unterrichtspraxis, 10, 102-108.

Phan, H. L. (2009). English as an international language: International students and identity formation. Journal of Language and Intercultural Communication, 9(3), 201-214.

Phillipson, R. (2009). Linguistic imperialism continued. New York, NY: Routledge.

Rashidi, N., Meihami, H., \& Gritter, K. (2016). Hidden curriculum: An analysis of cultural content of the ELT textbooks in inner, outer, and expanding circle countries. Cogent Education, 3(1), 1-17.

Richards, J. C., Hull, J., \& Proctor, S. (2005). Interchange series: Students' book 2 (3rd ed.). Cambridge: Cambridge University Press.

Richards, J. C., \& Schmidt, R. (2002). Dictionary of language teaching and applied linguistics (3rd ed.). London: Pearson Education.

Sadeghi, K., \& Sepahi, Z. (2018). Cultural content of three EFL textbooks: Teachers' and learners' cultural preferences and cultural themes of textbooks. Pedagogies: An International Journal, 13(3), 222-245.

Setyono, B., \& Puji Widodo, H. (2019). The representation of multicultural values in the Indonesian Ministry of Education and Culture-endorsed EFL textbook: a critical discourse analysis. Intercultural Education, 30(4), 383-397.

Sharifian, F. (Ed.). (2009). English as an international language: perspectives and pedagogical issues. Bristol: Multilingual Matters.

Sharifian, F. (2018). Glocalization of English. In J. Liontas (Ed.), TESOL encyclopedia of English language teaching. London: WileyBlackwell.

Sifakis, N. C. (2019). ELF awareness in English Language Teaching: principles and processes. Applied Linguistics, 40(2), $288-306$.

Sifakis, N. C., \& Bayyurt, Y. (2017). ELF-aware teacher education and development. In J. Jenkins, W. Baker, \& M. Dewey (Eds.), The Routledge handbook of English as a lingua franca (pp. 456-467). London: Routledge.

Siqueira, D. S. P. (2015). English as a lingua franca and ELT materials: Is the "Plastic World" really melting? In Y. Bayyurt \& S Ackan (Eds.), Current perspectives on pedagogy for English as a lingua franca (pp. 239-257). Berlin: De Gruyter Mouton.

Smith, L. (1976). English as an international auxiliary language. RELC Journal, 7(2), 38-43.

Syrbe, M., \& Rose, H. (2018). An evaluation of the global orientation of English textbooks in Germany. Innovation in Language Learning and Teaching, 12(2), 152-163.

Tajeddin, Z., Alemi, M., \& Pashmforoosh, R. (2018). Idealized native-speaker linguistic and pragmatic norms in English as an international language: Exploring the perceptions of nonnative English teachers. Language and Intercultural Communication, 18(3), 300-314.

Tajeddin, Z., \& Teimournezhad, S. (2015). Exploring the hidden agenda in the representation of culture in international and localised ELT textbooks. The Language Learning Journal, 43(2), 180-193.

Takahashi, R. (2011). English as a lingua Franca in a Japanese context: an analysis of ELF-oriented features in teaching materials and the attitudes of Japanese teachers and learners of English to ELF oriented materials (Unpublished doctoral dissertation). University of Edinburgh, Edinburgh, UK.

Tomlinson, B., \& Masuhara, H. (2013). Adult course books. ELT Journal, 67(2), 233-249.

Vettorel, P. (2010). EIL/ELF and representation of culture in textbooks: only food, fairs, folklore and facts? In C. Gagliardi \& A. Maley (Eds.), EIL, ELF, global English: teaching and learning issues (pp. 154-185). Bern: Peter Lang.

Vettorel, P. (2018). ELF and communication strategies: are they taken into account in ELT materials? RELC Journal, 49(1), 58-73.

Vettorel, P., \& Lopriore, L. (2017). WE, ElL, ELF and awareness of their pedagogical implications in teacher education programs in Italy. In A. Matsuda (Ed.), Preparing teachers to teach English as an international language (pp. 197-209). Bristol: Multilingual Matters.

Widdowson, H. G. (1994). The ownership of English. TESOL Quarterly, 28(2), 377-389.

Xiaoqiong, H., \& Xianxing, J. (2011). Kachru's three concentric circles and English teaching fallacies in EFL and ESL contexts. Changing English: Studies in Culture and Education, 18(2), 219-228.

Yamanaka, N. (2006). An evaluation of English textbooks in Japan from the viewpoint of nations in the inner, outer, and expanding circles. JALT Journal, 28(1), 57-76.

\section{Publisher's Note}

Springer Nature remains neutral with regard to jurisdictional claims in published maps and institutional affiliations. 